\title{
Pengaruh Ekstrak Daun Belimbing Wuluh (Averrhoa bilimbi Linn.) sebagai Bahan Dipping Puting terhadap Jumlah Coliform dan pH Susu
}

\author{
The Effect of Averrhoa bilimbi Leaves Extract as a Teat Dip Antiseptic to the Number of \\ Coliform and Milk $\mathrm{pH}$
}

\author{
G. E. Suhendar, P. Sambodho dan D. W. Harjanti \\ Laboratorium Produksi Ternak Potong dan Perah, Departemen Peternakan \\ Fakultas Peternakan dan Pertanian Universitas Diponegoro, Semarang \\ Email: dianharjanti@undip.ac.id
}

\begin{abstract}
This study aimed to determine the effect of Averrhoa bilimbi Linn. leaves extract as an antiseptic for postmilking teat dipping in reducing Coliform contamination in milk and its effect on milk $\mathrm{pH}$. The degree of udder inflammation also determined by California Mastitis Test. This study used completely randomized design (CRD) split plot types with 4 treatments and 4 replications. The treatments were 1\%, 2\%, and 5\% of Averrhoa bilimbi leaves extract (T1, T2 and T3, respectively). Commercially syntetic antiseptic povidone iodine was used as positive control $(\mathrm{K}+)$. Teat dipping was conducted every day after morning and evening milking for 9 days. Milk samples were collected at before treatment (H0) and on the day 3, 6 and 9 day of treatments (H3, H6 and H9, respectively). The results showed no interaction between the treatments and sampling days. The number of Coliform and $\mathrm{pH}$ in all treatment groups were similar. Moreover, it is showed that different sampling days had a highly significant effects $(\mathrm{P}<0.01)$ on the number of Coliform. The Coliform number on the day 9 was the lowest. In conclusion, Averrhoa bilimbi leaves extract is effective as antibacteria and its effectiveness is comparable with Povidone iodine. Hence, it can be used as an alternative for teat dip antiseptic. Teat dipping after milking must be done daily to prevent the Coliform contamination in milk.
\end{abstract}

Key words: Averrhoa bilimbi leaves, antiseptic, milk, Coliform, milk pH

\begin{abstract}
ABSTRAK
Penelitian ini bertujuan untuk mengetahui pengaruh ekstrak daun belimbing wuluh (Averrhoa bilimbi Linn.) sebagai larutan dipping puting dalam menurunkan jumlah cemaran Coliform pada susu, dan pengaruhnya terhadap $\mathrm{pH}$ susu. Pengaruh ekstrak terhadap tingkat peradangan ambing juga dideteksi menggunakan California Mastitis Test. Penelitian ini menggunakan Rancangan Acak Lengkap Berjenjang (split-plot in time), dengan empat kelompok perlakuan dan masing-masing empat ulangan. Perlakuan yang diberikan adalah pencelupan puting sapi perah ke dalam larutan yang mengandung 1\%, 3\% dan 5\% ekstrak daun Belimbing Wuluh (T1, T2 dan T3). Kontrol positif menggunakan antiseptik sintetis komersial berupa povidone iodine $(\mathrm{K}+)$. Pencelupan puting dilakukan setiap hari selama 9 hari, yaitu setelah pemerahan pagi dan sore. Sample susu diambil pada sebelum perlakuan dan pada hari ke-3, 6 dan 9. Hasil penelitian menunjukkan tidak ada interaksi antara perlakuan antiseptik dengan hari pengambilan sample disetiap pada parameter jumlah Coliform, pH susu, maupun tingkat peradangan ambing. Perbedaan perlakuan konsentrasi ekstrak dan povidon iodine menghasilkan penurunan Coliform dalam jumlah yang sama. Lama aplikasi dipping (3, 6 dan 9 hari) menunjukkan perbedaan yang sangat nyata $(\mathrm{P}<0,01)$ terhadap jumlah Coliform, dimana semakin jika dipping dilakukan secara rutin setiap hari maka jumlah Coliform semakin menurun. Simpulan dari penelitian ini adalah ekstrak daun Belimbing Wuluh terbukti efektif sebagai antibakteri dan dapat digunakan sebagai anternatif terhadap antiseptik sintetis komersial. Pencelupan putting sapi kedalam antiseptik setelah pemerahan harus selalu dilakukan secara rutin.
\end{abstract}

Kata kunci : daun Belimbing Wuluh, antiseptik, susu, Coliform, pH susu

\section{PENDAHULUAN}

Sapi perah merupakan salah satu komoditas peternakan yang hasil utamanya berupa susu. Susu merupakan bahan organik yang mudah terkontaminasi karena dapat menjadi sarana tumbuhnya dan tersebarnya mikroorganisme. 
Akibat kontaminasi tersebut dapat mempengaruhi jumlah mikroorganisme khususnya bakteri yang ada pada susu. Bakteri tersebut akan meningkat jumlahnya seiring pertambahan waktu. Menurut Standart Nasional Indonesia (2011) cemaran bakteri dalam susu adalah maksimal $1.000 .000 \mathrm{CFU} / \mathrm{ml}$. Akibat adanya pertambahan bakteri menjadikan susu tidak layak dan tidak aman untuk dikonsumsi manusia.

Salah satu bakteri patogen yang mengkontaminasi susu adalah kelompok bakteri Coliform. Bakteri kelompok Coliform merupakan mikroorganisme yang dijadikan sebagai indikator adanya cemaran pada susu. Bakteri patogen tersebut menyebabkan peradangan di dalam ambing sehingga susu yang keluar dari ambing terkontaminasi dan mengakibatkan kerugian yaitu penurunan produksi dan kualitas susu, peningkatan biaya perawatan dan pengobatan, pengafkiran sapi lebih awal serta pembelian sapi perah baru.

Penelitian Sugiri dan Anri (2010) diperoleh hasil bahwa dari 19 peternakan yang diperiksa di Pulau Jawa (Bandung Barat, Bandung, Cianjur, Banyumas, dan Pasuruan) 39\% susunya terinfeksi bakteri kelompok Coliform. Menurut Standart Nasional Indonesia (2011) batas cemaran bakteri Coliform pada susu segar adalah 20MPN/ml.

Menurut Yusuf (2011) untuk meminimalkan kandungan bakteri yang ada pada susu yaitu dengan cara seperti menghambat pertumbuhan bakteri atau dimatikan dengan perlakuan fisik atau dengan pemberian antiseptik. Pada penelitian ini perlakuan fisik yang digunakan adalah pencelupan puting/dipping puting dengan antiseptik alami untuk melapisi lubang puting agar bakteri tidak masuk dalam putting. Menurut Poeloengan (2009) menyatakan bahwa pengobatan dengan menggunakan antiseptik kimia dapat menyebabkan residu pada susu yang dapat membahayakan konsumen, diantaranya bisa terjadi keracunan, alergi dan gangguan pencernaan. Menurut Galton (2004), menggunakan iodosphor sebagai bahan dipping setelah pemerahan dapat meninggalkan residu iodine di dalam susu.

Salah satu bahan alami yang dapat dimanfaatkan sebagai antiseptik untuk dipping puting yaitu daun belimbing wuluh (Averrhoa bilimbi Linn.). Liantari (2014) menyatakan bahwa daun belimbing wuluh mengandung flavonoid, saponin dan tanin. Bahan aktif tersebut diduga memiliki khasiat sebagai antioksidan, antibakteri dan antiinflamasi.

Tujuan penelitian adalah untuk mengkaji peran ekstrak daun belimbing wuluh dalam menurunkan cemaran bakteri Coliform pada susu, menurunkan peradangan ambing yang diketahui dengan uji California Mastitis Test (CMT) pada susu dan pengaruhnya terhadap $\mathrm{pH}$ susu. Manfaat dari penelitian adalah untuk menemukan antiseptik alami untuk dipping puting yang aman kepada peternak sehingga dapat menggantikan antiseptik kimia untuk menurunkan cemaran bakteri. Hipotesis pada penelitian ini adalah efektivitas povidone iodine sama seperti 
ekstrak daun belimbing wuluh dalam menurunkan jumlah bakteri Coliform, menurunkan peradangan ambing dan pengaruhnya pada $\mathrm{pH}$ susu. Konsentrasi masing-masing ekstrak memiliki kemampuan berbeda dalam menurunkan jumlah bakteri Coliform, menurunkan nilai peradangan ambing dan pengaruhnya pada $\mathrm{pH}$ susu. Semakin hari dilakukan dipping puting akan berpengaruh pada jumlah bakteri Coliform, nilai peradangan ambing dan $\mathrm{pH}$ susu.

\section{MATERI DAN METODE}

Penelitian ini dilaksanakan pada tanggal 14 Desember-23 Desember 2015 di Unit Pelaksanaan Teknis Daerah (UPTD)Pembibitan Ternak Unggul Mulyorejo, Desa Barukan, Kecamatan Tengaran-Kabupaten Semarang.Materi yang digunakan adalah 16 ekor sapi perah yang terindikasi peradangan ambing yang diketahui dengan uji CMT, dengan umur sapi 3 tahun, bobot badan rata-rata 408,81 $\mathrm{kg}$, periode laktasi ke I bulan laktasi ke-3 dan ke-4, ekstrak daun belimbing wuluh, povidone iodine dan Reagen California Matitis Test. Peralatan yang digunakan adalah botol dipping, cawan paddle dan $\mathrm{pH}$ meter digital.

Paramater yang digunakan dalam penelitian ini adalah jumlah bakteri Coliform pada susu, $\mathrm{pH}$ susu dan tingkat peradangan pada ambing. Penelitian ini meliputi tiga tahap yaitu tahap pra penelitian, tahap perlakuan dan pengambilan data.

\section{Tahap pra penelitian}

Tahap ini membuat ekstrak daun belimbing wuluh. Pembuatan ekstrak menggunakan metode maserasi. Hasil dari $300 \mathrm{~g}$ tepung daun belimbing wuluh setelah diekstrak menjadi 43,86 $\mathrm{ml}$. Teknis pembuatan larutan ekstrak daun belimbing wuluh: a). $1 \%$ ekstrak daun belimbing wuluh ( $1 \mathrm{ml}$ ekstrak daun belimbing wuluh dan $99 \mathrm{ml}$ aquadest). b). 3\% ekstrak daun belimbing wuluh (3 $\mathrm{ml}$ ekstrak daun belimbing wuluh dan $97 \mathrm{ml}$ aquadest). c). $5 \%$ ekstrak daun belimbing wuluh $(5 \mathrm{ml}$ ekstrak daun belimbing wuluh dan $95 \mathrm{ml}$ aquadest) dan d). $5 \mathrm{ml}$ povidone iodine dan $95 \mathrm{ml}$ aquadest.

\section{Tahap perlakuan}

Pada tahap ini melakukan dipping puting selama 9 hari setelah pemerahan pagi dan sore menggunakan antiseptik alami yaitu ekstrak daun belimbing wuluh dan kontrol positif menggunakan povidone iodine selama 10 detik setelah pemerahan pagi dan sore. Konsentrasi ekstrak daun belimbing wuluh untuk perlakuan dipping putting sebagai berikut:

$\mathrm{K}+$ : Dipping puting dengan menggunakan povidone iodine.

T1: Dipping puting dengan menggunakan $1 \%$ ekstrak daun belimbing wuluh.

T2: Dipping puting dengan menggunakan $3 \%$ ekstrak daun belimbing wuluh.

T3: Dipping puting dengan menggunakan $5 \%$ ekstrak daun belimbing wuluh.

\section{Pengambilan data}

Tahap ini dilakukan pada hari ke0,3, 6 dan 9 menggunakan susu pemerahan 
pagi yang meliputi : Perhitungan jumlah bakteri Coliformdengan cara mengambil sample susu kemudian di lakukan perhitungan bakteri Coliform terhadap sample susu di Balai Kesehatan Masyarakat Veteriner Boyolali. Perhitungan jumlah bakteri Coliform menggunakan Metode Most Probable Number (MPN) yang terdiri dari uji presumtif (pendugaan) dan uji konfirmasi (peneguhan), dengan menggunakan mediaagar Brilliant Green Lactose Bile Broth (BGLBB), media agar Lauryl Sulfate Triptose Broth (LSBT)dan larutan pengencer Buffer Peptone Water (BPW) $0,1 \%$, dan uji dilakukan berdasarkan jumlah tabung positif. Pengamatan tabung positif dapat dilihat dengan timbulnya gas di dalam tabung Durham. Perhitungan dan metode ini sesuai dengan SNI tahun 2008.
Pengukuran $\mathrm{pH}$ susu dilakukan dengan cara menyelupkan elektroda ke dalam susu sampai $\mathrm{pH}$ meter menunjukkan angka pembacaan yang tetap. Setelah itu mencatat hasil pembacaan skala atau angka pada tampilan dari $\mathrm{pH}$ meter.

Pengujian Skor CMT dilakukan dengan cara meletakkan sampel susu curahan ketiga dari keempat puting sapi sebanyak $2 \mathrm{ml}$ pada cawan paddle, selanjutnya sampel ditambahkan reagen CMT jumlahnya sama dengan volume susu lalu dihomogenkan dengan cara memutar cawan membentuk pola angka delapan secara perlahan-lahan selama 10 detik kemudian diamati perubahan fisik susu. Tahap selanjutnya adalah pemberian nilai peradangan ambing menggunakan interprestasi skor CMT pada Tabel 1. untuk mengetahui jumlah sel somatik dan mempermudah perhitungan statistik.

Tabel 1. Interpretasi pemberian nilai pada skor CMT

\begin{tabular}{cclc}
\hline Kode & $\begin{array}{c}\text { Jumlah Sel } \\
\text { Somatik(sel/ml })\end{array}$ & \multicolumn{1}{c}{ Deskripsi } & $\begin{array}{c}\text { Nilai Peradangan } \\
\text { Ambing }\end{array}$ \\
\hline- & $0-480.000$ & $\begin{array}{l}\text { Tidak terjadi pengentalan pada } \\
\text { susu } \\
\text { Sedikit terjadi pengetalan dan } \\
\text { menghilang dalam waktu 10 } \\
\text { detik } \\
\text { Ada pengentalan dalam tetapi } \\
\text { belum terbentuk gel } \\
\text { Mengental dan membentuk } \\
\text { sedikit gel dalam waktu } \\
\text { Mengental dan terbentuk banyak } \\
\text { gel diseluruh sampel }\end{array}$ & 2 \\
++ & 640.000 & 2 & 3 \\
\hline
\end{tabular}

Sumber: Aziz et al. (2011)

\section{Analisis Data}

Penelitian ini menggunkan Rancangan Acak Lengkap Berjenjang Waktu (Split-Plot in Time). Analisis rancangan Split-Plot in Time dibagi menjadi dua petak yatu petak utama (main plot) dan anak petak (sub plot). Main plot dalam penelitian ini adalah konsentrasi 
ekstrak daun belimbing wuluh masingmasing $1 \%, 3 \%, 5 \%$ dan povidone iodine sebagai kontrol. Sub plot pada penelitian ini adalah waktu pengambilan sample yaitu hari ke-0, 3, 6 dan 9 dengan 4 ulangandilanjutkan dengan uji Duncan's Multiple Range Test (DMRT).

\section{HASIL DAN PEMBAHASAN}

\section{Pengaruh Perlakuan terhadap Jumlah Bakteri Coliform}

Hasil analisis jumlah bakteri Coliform pada susu akibat dipping puting dengan menggunakan konsentrasi anteseptik yang berbeda dan hari pengambilan sample yang berbeda disajikan pada Tabel 2.

Tabel 2. Rataan jumlah bakteri Coliform pada susu

\begin{tabular}{cccccc} 
Konsentrasi & \multicolumn{4}{c}{ Hari Pengambilan Sample } & \multirow{2}{*}{ Rataan } \\
\cline { 2 - 4 } Antiseptik & H0 & H3 & H6 & H9 $n n$ & \\
\hline & & $-----($ MPN/ml) & ----- \\
K+ & 828,75 & 65,55 & 19,6 & 5,15 & 229,76 \\
T1 & 562,5 & 235 & 27,05 & 3,00 & 206,89 \\
T2 & 572,75 & 137 & 22,1 & 3,15 & 183,89 \\
T3 & 436,5 & 92,85 & 18,6 & 4,55 & 138,10 \\
\hline Rataan & $600,12^{\mathrm{A}}$ & $132,6^{\mathrm{B}}$ & $21,86^{\mathrm{C}}$ & $3,96^{\mathrm{D}}$ \\
\hline
\end{tabular}

Keterangan: Superskrip yang berbeda pada baris rataan hari pengambilan sample yang sama menunjukkan perbedaan sangat nyata $(\mathrm{P}<0,01)$.

Tabel 2 menunjukkan perlakuan $\mathrm{K}+, \mathrm{T} 1, \mathrm{~T} 2$ dan T3 tidak menunjukkan pengaruh yang nyata $(\mathrm{P}>0,05)$ sehingga dapat diketahui bahwa penggunaan ekstrak daun belimbing wuluh dengan konsentrasi bertingkat jika dibandingkan dengan penggunaan povidone iodine tidak menunjukkan perbedaan yang nyata dalam menurunkan cemaran bakteri Coliform.

Hal ini terlihat pada rataan jumlah bakteri Coliform akibat konsentrasi dipping. Perlakuan $\mathrm{K}+$ rataan jumlah bakteri yaitu 229,76 MPN/ml, angka tersebut tidak memiliki perbedaan yang nyata jika dibandingkan dengan rataan jumlah bakteri Coliform pada T1 (1\%) yaitu sebesar 206,89 MPN/ml. Begitu pula pada perlakuan T2 (3\%) dan T3 (5\%), rataan jumlah bakteri secara berturut-turut adalah 183,75 MPN/ml dan 138,10 $\mathrm{MPN} / \mathrm{ml}$ rataan tersebut tidak menunjukkan selisih yang nyata dengan rataan jumlah bakteri pada perlakuan $\mathrm{K}+$. Berdasarkan data tersebut maka diketahui bahwa perlakuan $\mathrm{K}+$ menggunakan povidone iodine jika dibandingkan dengan antiseptik ekstrak daun belimbing wuluh dengan konsentrasi bertingkat memiliki efektivitas yang sama dalam menurunkan jumlah bakteri Colifrom. Diduga karena zat aktif yang ada pada ekstrak daun belimbing wuluh memiliki kemampuan yang sama dengan zat aktif yang ada pada povidone iodine dalam menekan jumlah bakteri Coliform.

Zat aktif yang ada pada ekstrak daun belimbing wuluh terdiri dari flavonoid, saponin dan tanin. Fungsi dari 
flavonoid menurut Liantari (2014) adalah flavonoid mampu membentuk kompleks dengan protein bakteri melalui ikatan hidrogen. Keadaan ini menyebabkan struktur dinding sel dan membran sitoplasma bakteri yang mengandung protein menjadi tidak stabil sehingga sel bakteri menjadi kehilangan aktivitas biologinya dan selanjutnya sel bakteri akan mengalami lisis yang berakibat pada kematian sel bakteri. Menurut Fahrunnida dan Pratiwi (2015), saponin merupakan senyawa yang memiliki tegangan permukaan yang kuat sehinggamampu mengganggu kestabilan membran sel bakteri yang menyebabkan lisis sel bakteri tersebut. Senyawa tanin menurut pendapat Mukhlisoh (2010) merupakan growth inhibitor, sehingga senyawa ini memiliki kemampuan menghambat sintesis dinding sel bakteri dan sintesis protein sel kuman gram positif maupun gram negatif.

Penggunaan antiseptik ekstrak daun belimbing wuluh dengan konsentrasi bertingkat T1 (1\%), T2 (3\%) dan T3 (5\%) tidak menunjukkan pengaruh yang nyata $(\mathrm{P}>0,05)$, hal tersebut terlihat tidak adanya selisih yang berbeda pada rataan jumlah Coliform di setiap masing-masing konsentrasi ekstrak daun belimbing wuluh. Kondisi ini menunjukkan bahwa penggunaan antiseptik ekstrak daun belimbing wuluh dengan konsentrasi $\mathrm{T} 1$ (1\%) memiliki kemampuan yang sama dengan konsentrasi T2 (3\%) dan T3 (5\%) dalam menurunkan jumlah bakteri Coliform, maka dapat diketahui perlakuan konsentrasi T1 (1\%) merupakan dosis yang disarankan untuk dipping dan dinilai lebih ekonomis jika diaplikasikan ke peternak sapi perah.

Berdasarkan analisis ragam (ANOVA), hari pengambilan sample menunjukkan pengaruh yang sangat nyata $(\mathrm{P}<0,01)$ terhadap rataan jumlah bakteri Coliform. Rataan jumlah bakteri pada pengambilan sample hari ke-0,3,6 dan 9 secara berturut-turut adalah 600,12 $\mathrm{MPN} / \mathrm{ml} ; 132,6 \mathrm{MPN} / \mathrm{ml} ; 21,86 \mathrm{MPN} / \mathrm{ml}$ dan 3,96 MPN/ml. Rataan jumlah bakteri Coliform pada hari ke-0 sebesar 600,12 $\mathrm{MPN} / \mathrm{ml}$. Jumlah tersebut sangat tinggi melebihi batas cemaran bakteri Coliform pada susu. Menurut Standart Nasional Indonesia (SNI) (2011) batasan cemaran bakteri Coliform pada susu adalah 20 MPN/ml. Besarnya jumlah bakteri Coliform pada hari ke-0 dikarenakan belum dilakukan perlakuan fisik yaitu dipping puting sehingga, lubang puting tetap terbuka saat setelah pemerahan dan menyebabkan bakteri dapat masuk kedalam puting. Hal tersebut sesuai dengan pendapat Jones (2009) yang menyatakan bahwa setelah pemerahan, otot sphincter akan terbuka selama 1-2 jam sehingga pada waktu tersebut bakteri dapat masuk ke dalam lubang puting. Ditambahakan oleh pendapat Safangat et al. (2014) yang menyatakan bahwa tingkat kelenjar mammae mencapai titik terendah saat sesudah pemerahan, karena sphincter masih terbuka beberapa saat, sel darah putih, antibodi serta enzim juga habis ikut terperah. Hari ke-3 dan hari ke-6 jumlah bakteri Colifrom mengalami penurunan secara berturut-turut yaitu menjadi 132,6 MPN/ml dan 21,86 MPN/ml. Hari ke-9 
jumlah bakteri Coliform pada susu sebesar3,96 MPN/ml jumlah tersebut jauh dibawah batas jumlah bakteri Coliform menurut SN1(2011) yaitu sejumlah 20 MPN/ml. Penurunan terjadi diduga karena semakin lama dilakukan dipping puting maka semakin efektif kerja dari ekstrak daun belimbing wuluh dalam melapisi lubang puting sehingga bakteri tidak dapat masuk kedalam ambing. Uraian tersebut sesuai dengan pendapat Mahardhika et al. (2012) yang menyatakan bahwa zat aktif pada bahan dipping akan menutup saluran puting sehingga bakteri yang ada di luar tidak dapat masuk meskipun lubang puting terbuka, karena terhalang oleh lapisan bahan dipping, dengan kondisi tersebut kerusakan susu akibat bakteri dapat terhindarkan.

Berdasarkan uji lanjut diperoleh hasil bahwa adanya penurunan yang sangat nyata disetiap hari pengambilan sample. Hal ini terlihat pada Tabel 2, disetiap hari pengambilan sample menunjukkan superskrip yang berbeda pada baris rataan bakteri Coliform. Perbedaan superskrip tersebut menandakan bahwa disetiap hari pengambilan sample, rataan bakteri Coliform mengalami penurunan yang berbeda. Pada kondisi ini perlakuan dipping selama 9 hari secara berkelanjutan mampu menurunkan jumlah bakteri Coliform pada susu. Berdasarkan uraian tersebut, diketahui bahwa ekstrak daun belimbing wuluh dapat dijadikan bahan alternatif untuk dipping puting karena semakin lama dilakukan dipping maka dapat mencegah masuknya bakteri Coliform kedalam ambing sehingga cemaran bakteri Coliform pada susu dapat berkurang.

\section{Pengaruh Perlakuan terhadap Nilai pH Susu}

Hasil analisis pH pada susu akibat dipping puting dengan menggunakan konsentrasi anteseptik yang berbeda dan hari pengambilan sample yang berbeda disajikan pada Tabel 3 .

Perlakuan ekstrak daun belimbing wuluh T1 (1\%), T2 (3\%) dan T3 (5\%) untuk dipping puting tidak menunjukkan pengaruh yang nyata $(\mathrm{P}>0,05)$ dengan perlakuan dipping menggunakan povidone iodine $(\mathrm{K}+)$. Terlihat pada perlakuan $\mathrm{K}+$ nilai $\mathrm{pH}$ susu 6,68 tidak berbeda nilainya dengan perlakuan T1,T2 dan T3 yaitu secara berturut-turut 6,73:6,73 dan 6,69. Tidak adanya perbedaan diduga karena kemampuan zat aktif yang ada pada ekstrak daun belimbing wuluh sama dengan kemampuan zat aktif yang ada pada povidone iodine dalam mempertahankan $\mathrm{pH}$ susu pada keadaan normal.

Berdasarkan analisis ragam (ANOVA), diketahui bahwa hari pengambilan sample menunjukkan pengaruh yang sangat nyata $(\mathrm{P}<0,01)$. Terlihat pada tabel 3 bahwa hari pengambilan sample mempengaruhi nilai $\mathrm{pH}$ susu.Selain menurunkan jumlah bakteri Coliform, hari pengambilan sample juga mampu mempertahankan nilai $\mathrm{pH}$ susu sampai hari ke-9. Nilai $\mathrm{pH}$ susu pada hari ke-0, 3, 6 dan 9 secara berturut-turut adalah 6,$61 ; 6,70 ; 6,72$ dan 6,79. Nilai pH sampai hari ke-9 tetap terjaga dalam 
e-ISSN 2528-7109

p-ISSN 1978-3000

keadaan normal sesuai dengan Standart

berkisar 6,3- 6,8.

Nasioanal Indonesia (SNI) (2011) yaitu

Tabel 3. Rataan $\mathrm{pH}$ pada susu

\begin{tabular}{cccccc}
\hline \multirow{2}{*}{$\begin{array}{c}\text { Konsentrasi } \\
\text { Antiseptik }\end{array}$} & \multicolumn{4}{c}{ Hari Pengambilan Sampel } & \multirow{2}{*}{ Rataan } \\
\cline { 2 - 4 } & H0 & H3 & H6 & H9 $n n$ \\
K+ & 6,58 & 6,68 & 6,68 & 6,80 & 6,68 \\
T1 & 6,60 & 6,73 & 6,75 & 6,83 & 6,73 \\
T2 & 6,68 & 6,75 & 6,73 & 6,78 & 6,73 \\
T3 & 6,60 & 6,65 & 6,73 & 6,78 & 6,69 \\
\hline Rataan & $6,61^{\mathrm{c}}$ & $6,70^{\mathrm{b}}$ & $6,72^{\mathrm{b}}$ & $6,79^{\mathrm{a}}$ & \\
\hline
\end{tabular}

Keterangan: Superskrip yang berbeda pada baris rataan hari pengambilan sampel yang sama menunjukkan perbedaan yang sangat nyata $(\mathrm{P}<0,01)$.

Nilai pH susu hari ke-0 adalah 6,61, nilai tersebut cenderung asam dibandingkan hari selanjutnya, ini diduga karena pada hari ke-0 belum dilakukan dipping puting, dapat dilihat juga pada Tabel 3 jumlah bakteri Coliform pada hari ke-0 juga tinggi. Jumlah bakteri mempengaruhi nilai $\mathrm{pH}$ susu. Uraian tersebut sesuai dengan pendapat Swadayana et al. (2012) yang menyatakan bahwa nilai $\mathrm{pH}$ dan jumlah bakteri sangat berhubungan erat, semakin banyak jumlah bakteri dalam susu maka nilai $\mathrm{pH}$ akan menurun akibat terjadinya banyak pengasaman oleh aktivitas bakteri. Nilai $\mathrm{pH}$ terus mengalami kenaikan pada hari ke-3 dan ke-6 tetapi tetap berada pada kisaran normal dan puncaknya pada hari ke-9 nilai pH sebesar 6,79. Kenaikan tersebut diduga karena berkurangnya aktivitas bakteri yang memecah laktosa menjadi asam laktat. Hal tersebut sesuai dengan pendapat Putri et al. (2015) yang menyatakan bahwa kenaikan dan penurunan $\mathrm{pH}$ susu disebabkan oleh konversi dari laktosa menjadi asam laktat akibat aktivitas enzimatik bakteri. Ditambahkan oleh pendapat Yusuf (2012) bahwa salah satu ciri bakteri Coliform adalah dapat menfermentasikan laktosa dengan menghasilkan asam laktat dan gas.

Berdasarkan uji lanjut, diketahui bahwa terdapat perbedaan yang sangat nyata pada setiap hari pengambilan sampel terhadap nilai $\mathrm{pH}$ susu. Hal tersebut diketahui disetiap hari pengambilan sample memiliki superskrip yang berbeda pada baris rataan nilai $\mathrm{pH}$. Nilai $\mathrm{pH}$ susu pada hari ke-0 cenderung asam yaitu 6,61. Pada hari ke-3 pada superskrip yang berbeda nilai $\mathrm{pH}$ susu cenderung meningkat mendekati kondisi normal yaitu 6,70 dan terjadi pula pada hari ke-9 dimana kondisi pH susu mengalami kenaikan menjadi 6,79. Dapat disimpulkan dari uraian tersebut bahwa semakin lama dilakukan dipping puting dengan ekstrak daun belimbing wuluh maka jumlah bakteri Coliform berkurang sehingga pengasaman susu yang diakibatkan oleh aktivitas bakteri terhindarkan dan nilai $\mathrm{pH}$ susu tetap pada kisaran normal. 
Pengaruh Perlakuan terhadap Nilai Peradangan Ambing

Berdasarkan analisis ragam (ANOVA), diketahui bahwa masingmasing konsentrasi ekstrak daun belimbing wuluh dan hari pengambilan sample tidak menunjukkan perbedaan yang nyata ( $\mathrm{P}>0,05)$. Perlakuan dipping puting menggunakan ekstrak daun belimbing wuluh sebagai dipping dengan konsentrasi $\mathrm{T} 1(1 \%), \quad \mathrm{T} 2$ (3\%) dan $\mathrm{T} 3(5 \%)$ tidak mampu menurunkan nilai peradangan ambing pada susu, begitu juga dengan perlakuan hari pengambilan sampel. Tidak adanya pengaruh disetiap perlakuan diduga karena dipping puting hanya berfungsi melapisi lubang puting, sehingga zat aktif yang ada pada ekstrak daun belimbing wuluh tidak dapat masuk ke dalam puting menjangkau peradangan yang ada didalam ambing. Hal tersebut sesuai dengan pendapat Kurnianto et al. (2015) yang menyatakan bahwa dipping puting merupakan pencelupan puting dengan menggunakan antibakteri agar bakteri yang ada disekitar puting tidak masuk.

Tabel 4 menunjukkan bahwa rataan nilai peradangan ambing pada hari ke-0, 3 , 6 dan 9 secara berturut-turut adalah 2,9;
2,$8 ; 2,6$ dan 2,5. Nilai peradangan ambing tersebut tidak mengalami penurunan sampai hari terakhir. Nilai peradangan ambing tersebut mengandung jumlah sel somatik sangat tinggi didalam susu. Nilai peradangan ambing berkisar antara 2,5-2,9 dan dapat dibulatkan menjadi 3. Jika dilihat pada Tabel 1, peradangan ambing dengan nilai 3 memiliki sel somatik sejumlah 2.400.000 sel/ml. Jumlah sel somatik tersebut terbilang sangat tinggi dan melebihi batas jumlah sel somatik menurut Standart Nasional Indonesia (SNI) (2011) yaitu sebesar $400.000 \mathrm{sel} / \mathrm{ml}$. Tidak terjadinya penurunan diduga karena peradangan yang ada di dalam ambing cukup serius. Menurut Ahmad (2011) peradangan ambing terjadi akibat bakteri mengalami multiplikasi di sekitar lubang puting setelah itu bakteri masuk ke dalam lubang puting dan terjadilah respon imun pada induk semang. Respon pertahanan pertama ditandai dengan berkumpulnya lekosit-lekosit untuk mengeliminasi mikroorganisme yang telah menempel pada sel-sel ambing. Apabila respon ini gagal, maka bakteri akan mengalami multiplikasi dan sel somatik yang ada pada susu semakin banyak jumlahnya.

Tabel 4. Rataan nilai peradangan ambing pada susu

\begin{tabular}{cccccc}
\hline Konsentrasi & \multicolumn{4}{c}{ Hari Pengambilan Sampel } & \multirow{2}{*}{ Rataan } \\
\cline { 2 - 4 } Antiseptik & H0 & H3 & H6 & H9 & \\
\hline & & ------------------- & & \\
K+ & 2,8 & 2,8 & 3,0 & 2,5 & 2,8 \\
T1 & 2,8 & 2,8 & 2,3 & 2,5 & 2,7 \\
T2 & 3,0 & 2,5 & 2,3 & 2,8 & 2,6 \\
T3 & 3,0 & 3,0 & 2,8 & 2,3 & 2,8 \\
\hline Rataan & 2,9 & 2,8 & 2,6 & 2,5 & \\
\hline
\end{tabular}

Keterangan: Tidak ada pengaruh yang nyata pada rataan konsentrasi dan rataan hari pengambilan sample terhadap nilai peradangan ambing $(\mathrm{P}>0,05)$. 
Ditambahkan oleh Susanti dan Nurdin (2012), bahwa peradangan dalam pada ambing disebabkan oleh bakteri patogen yang menyebabkan kerusakan sel sekretoris ambing sehingga sintesa lemak, laktosa, kasein dan protein menurun.

Berdasarkan uraian diatas dapat disimpulkan bahwa dipping puting menggunakan ekstrak daun belimbing wuluh tidak dapat menyembuhkan peradangan pada ambing, karena dipping puting berfungsi hanya untuk melapisi lubang puting dan mencegah masuknya bakteri patogen kedalam ambing melalui puting. Menurut Swartz (2006), pengobatan untuk menyembuhkan peradangan pada ambing sapi dilakukan dengan cara penyuntikan antibiotik intramammary.

\section{KESIMPULAN}

Berdasarkan hasil penelitian, disimpulkan bahwa dipping puting mengunakan ekstrak daun belimbing wuluh dengan konsentrasi $1 \%$ sudah cukup berpengaruh dalam menurunkan jumlah Coliformdan memiliki kemampuan sama sepertipovidone iodine. Dipping puting dengan ekstrak daun belimbing wuluh juga mampu menjaga $\mathrm{pH}$ susu dalam keadaan normal. Semakin lama dilakukan dipping puting maka kerja ekstrak daun belimbing wuluh mampu mencegah masuknya bakteri kedalam ambing sehingga jumlah bakteri berkurang dalam susu dan pengasaman yang terjadi oleh aktivitas bakteri berkurang sehingga nilai $\mathrm{pH}$ susu dapat dipertahankan pada keadaan normal.
Namun demikian, dipping puting dengan ekstrak daun belimbing wuluh belum mampu menyembuhkan peradangan di dalam ambing.

Peningkatan konsentrasi ekstrak daun belimbing wuluh perlu dilakukan untuk menurunkan jumlah bakteri dan menyembuhkan peradangan di dalam ambing. Peradangan ambing yang sudah parah dapat disembuhkan dengan cara penyuntikan antibiotik intrammamary.

\section{DAFTAR PUSTAKA}

Ahmad, R. Z. 2011. Mastitis mikotik di Indonesia. Balai Besar Penelitian Veteriner. Prosiding Seminar Nasional Teknologi Peternakan dan Veteriner: 403-410.

Aziz, A. S., P. Surjowardojo dan Sarwiyono. 2013. Hubungan bahan dan tingkat kebersihan lantai kandang terhadap kejadian mastitis melalui uji California Mastitis Test (CMT) di Kecamatan Tutur Kabupaten Pasuruan. J. Ternak Tropika 14 (2): 72-81.

Fahrunnida dan R. Pratiwi. 2015. Kandungan Saponin Buah, Daun dan Tangkai Daun Belimbing Wuluh (Averrhoa bilimbi L.). Prosiding Seminar Nasional Konservasi dan Pemanfaatan Sumber Daya Alam: 220-224.

Galton, D. M. 2004. Effects of an automatic postmilking teat dipping system on new intramammary 
infections and iodine in milk. J. Dairy Sci. 87:225-231.

Jones, G.M. 2009. Understanding the Basics of Mastitis. Virginia Cooperative Extension. Publication 404-233. http://pubs.ext.vt.edu/404/404233/404233.html. [Diakses tanggal 18 November 2015].

Kurnianto, D., Sarwiyono dan P. Surjowardjojo. 2015. Daya hambat jus daun kelor (Moringa oleifera) terhadap pertumbuhan bakteri Staphylococcus aureus dan Escherichia coli penyebab penyakit mastitis pada sapi perah. J. Ilmiah Ilmu-Ilmu Peternakan, 23(3): 27-31

Liantari, D.S. 2014. Effect of wuluh starfruit leaf extract for Streptococcus mutans growth. J. Majority 3(7): 27-33.

Mahardhika, O., Sudjatmogo, dan T. H. Suprayogi. 2012. Tampilan total bakteri dan $\mathrm{pH}$ pada susu kambing perah akibat dipping desinfektan yang berbeda. Anim. Agric. J. 1(1): 819 -828.

Mukhlisoh, M. 2010. Pengaruh Ekstrak Tunggal dan Gabungan Daun Belimbing Wuluh (Averrhoa bilimbi Linn) terhadap Efektivitas Antibakteri secara in vitro. Jurusan Kimia, Fakultas Sains dan Teknologi, Universitas Islam Negeri Maulana Malik Ibrahim,
Malang. (Skripsi Sarjana Pendidikan Kimia).

Putri, P., Sudjatmogo dan T.H. Suprayogi. 2015. Pengaruh lama waktu dippingdengan menggunakan larutan kaporit terhadap tampilan total bakteri dan derajat keasaman susu sapi perah. Anim. Agric. J. 4(1): 132-136.

Poeloengan, M. 2009. Aktivitas air perasan dan ekstrak etanol daun encok terhadap bakteri yang diisolasi dari sapi mastitis subklinis. Balai Besar Penelitian Veteriner, Bogor. Prosiding Seminar Nasional Teknologi Peternakan dan Veteriner: 300-305.

Safangat, A., Sarwiyono dan P. Surjowardjojo. 2014. Pengaruh Penggunaan Jus Daun Kelor (Moringa oleifera) untuk Teat Dipping terhadap Kejadian Mastitis Sub Klinis Sapi Perah Fries Holland Laktasi. Fakultas Peternakan, Universitas Brawijaya, Malang. Skripsi.

Sugari, Y. D dan A. Anri. 2010. Prevalensi patogen penyebab mastitis subklinis (Staphylacoccus aureus dan Streptococcus agalactiae) dan patogen penyebab mastitis subklinis lainnya pada peternakan skala kecil dan menengah di beberapa sentra peternakan sapi perah di Pulau Jawa. Japan International Cooperation Agency 
(JICA) Short Term Expert on Mastitis Control, Large Animal Clinic and Research Center (LACRC) Hokkaido Nosai. Hokkaido, Japan.

Susanti, H. dan E. Nurdin. 2012. Efek pemberian temu putih (Curcuma zedoaria) terhadap kualitas susu sapi perah penderita mastitis subklinis. J. Peternakan Indonesia 14(2): 368-372.

Swartz, H. A. 2006. Mastitis in The Ewe. http://www.caseagworld.com/caw. Lumast.html. Diakses pada tanggal 23 Juli 2016.

Swadayana, A., P. Sambodho, dan C. Budiarti. 2012. Total bakteri dan
$\mathrm{pH}$ susu akibat lama waktu dipping puting kambing peranakan etawa laktasi. Anim. Agric. J. 1(1): 12 - 21 .

SNI. 2008. Metode Pengujian Cemaran Mikroba dalam Daging, Telur dan Susu, serta Hasil Olahannya. BSN, Jakarta.

SNI. 2011. Susu segar-Bagian 1: Sapi, BSN, Jakarta.

Yusuf, A. 2011. Tingkat Kontaminasi Escherichia Coli pada Susu Segar di Kawasan Gunung Perak, Kabupaten Sinjai. Skripsi. Program Studi Produksi Ternak, Fakultas Peternakan, Universitas Hasanuddin, Makassar. 